\title{
How Two English Primary Schools Promote Wellbeing
}

JANE JONES

\begin{abstract}
This article is about how two English primary schools promote the wellbeing of primary-aged children and their teachers. No longer a privileged space for adults, wellbeing is increasingly a concern for children who, today, are subject to considerable stress. We currently inhabit a landscape of worry and pressure, often emanating from messages from news and social media that impact on children's lives. Schools in the UK have excellent pastoral arrangements and have embraced the challenge of ensuring the wellbeing of their pupils and teachers as a fundamental right. The Personal, Social, Health, and Economic (PSHE) national arrangements for schools in England that I describe give details of the requirements for promoting the physical and mental wellbeing of pupils. Against this policy backdrop, I undertook to observe life in each of two schools and to interview their head teachers and the class teachers of 6-7-year-olds to understand how each school enacted wellbeing measures. The research question was simply "How do these schools understand and enact wellbeing for the children, and their teachers?" The schools were chosen as they were contextually very different but well-known in the community for the excellence of their pastoral and PSHE provision. I matched my data to the core theme of 'Health and Wellbeing' in the PSHE programme of study. The findings show how wellbeing is both readily identifiable as a "subject" in the primary curriculum and also embedded into the school culture and across the curriculum. The findings also emphasise the importance of the teacher as the one with daily contact and in prime position to observe and come to know and understand each child. The teachers emphasised the need to help children to build resilience and confidence to enable them to take advantage of opportunities and cope constructively with challenges in their exercise of life choices. I conclude that it is the whole school culture of wellbeing that foregrounds the conditions in which children can learn and develop their wellbeing in school and in the wider community.
\end{abstract}

Keywords: wellbeing, mental health, primary curriculum, pupil voice, school culture

\section{INTRODUCTION}

The concept of wellbeing has become an existential phenomenon of modern times. It is also associated with a new positive focus on mental health in soci- etal attitudes. Society has become more transparent in recent years about the need to recognise and be supportive of mental health issues and to actively promote wellbeing. The current focus on wellbeing arguably reflects the pressures of modern life 
and has become legitimised, more open, and less stigmatised over recent years (Stirling \& Emery, 2016). This positioning is opposed to health issues that in the past were often associated negatively with mental illness. Wellbeing, however positively charged, is an amorphous, rather loose concept, susceptible to a multitude of interpretations (White, 2005), as will be discussed.

Layard and Dunn (2009) write that a consideration of the wellbeing of children is critical in promoting good childhood experiences. Children are exposed to relentless media output. $52 \%$ of threeto-four-year-old children have their own I-pad and are online nine hours a week according to a survey by the OECD (2019); in this environment the glorification of the fittest/richest/most influential is an inexorable message, as is a proliferation of disturbing images of violence and disasters. Such messages impact on children's lives, even the very young, who, with their innocence and inexperience, are naturally gullible, sensitive, and easily persuadable. Foremost is the influence of the harmful aspects of social media - unsuitable sites, peer pressure, competitiveness, unkindness, and increasing cyber-bullying from peers (Shariff \& Hoff, 2009). Li (2008), reporting on the growth of cyberbullying in junior high schools in Canada, found a reluctance on the part of most children to report it on the grounds that the children thought this would make the situation worse and also a belief that their parents would consequently restrict their access to technology. The power of the need for personal access to technology and dependency on it is a matter of concern.

Child poverty is a huge threat to child wellbeing and, far from being eradicated, along with family homelessness, even in the wealthiest countries, is worryingly prevalent, with the gap between rich and poor widening (Redmond for UNICEF, 2007). In the UK in the financial year ending 2019, the top $10 \%$ of the wealthiest increased their wealth four times faster than the bottom $10 \%$, according to the Office for National Statistics, UK (2020). Research by Bradshaw and Richardson (2009) across 27 countries in Europe found a link between a lack of wellbeing and material and housing circumstances; on the basis of data gained from the selfcompletion of questionnaires by children, Tomlinson et al. (2008) concluded that impoverished households directly impacted on children's wellbeing. Consequently, schools in many contexts have increasingly had to take on dimensions of social service support in addition to their primary function of education.

Policy guidelines such as the report by the Department for Education (2016) in England on mental health and behavioural issues for schools mirror recent shifts of definition. The main shift has been from medicalised definitions of mental health and wellbeing, largely defined by objective indicators such as family income, housing, education, and health (European Commission, 2011), towards an inclusive and subjective experience of physical, emotional, and social factors - that is to say, 
taking on board the views of the individual. This EC report shows how wellbeing is perceived, measured, and conceptualised across a range of European countries. New policy perspectives focus on both the immediate situation as well as on future lives, as the report by Sterling and Emery (2016) for the National Children's Bureau shows. Stratham and Chase (2010) assert that today's conceptualisation of wellbeing must take into account subjective as well as objective measures. In other words, children's rights and their entitlement to a say in how their own wellbeing is defined are now part of policy expectation and research (Pollard \& Lee, 2003; Pedace, 2008). Although it is difficult to compare wellbeing factors across cultural variables, several reports have been published in this domain (European Commission, 2008; OECD, 2009; UNICEF, 2007) that identify core wellbeing factors as above with both objective indicators and subjective evaluations. Contexts may vary and other variables come into play, such as gender differences and changed perceptions as children grow older, as in the research of Rees et al. (2009), who found that older children define wellbeing more in alignment with friends and that family and school matters decline in importance. Bradshaw et al. (2011) also identified the importance ascribed to their friends by young children. Regardless of context, certain material and relational needs remain central to children's wellbeing.

Research by Steger (2017) suggests that people function more effectively in both their personal and work lives when they have a sense of meaning or purpose and a sense of direction and can connect to there being a wider sense of purpose to something. Crucially, individuals need to experience a subjective feeling of daily achievement, which is where teachers are in a unique position to provide pedagogical scaffolding and emotional support for this purpose. The present investment by schools in children's wellbeing is apt and timely. My research question, "How do these schools understand and enact wellbeing for the children, and their teachers?", reflects this concern.

\section{Defining WELlbeING}

There is consensus only on the fact that wellbeing is a contested term and difficult to define. Ereaut and Whiting (2008, p. 7) describe wellbeing as " a social construct and site of contest", beset by multiple discourses. Stratham and Chase (2010, p. 12) define it is as "the quality of people's lives ... understood both in relation to objective measures such as ... health and subjective measures such as ... happiness". What is problematic about this is that it begs the question of what "quality of life" means. It is often associated with a "preoccupation with affluence" or the "happy but poor" trope, neither of which, according to White (2005), is satisfactory or appropriate. Dictionary definitions of wellbeing likewise tend towards states of happiness, healthiness, and prosperity whilst ignoring disharmony and ill-being. There is, according to the literature, some consensus about the 
need for balance, equilibrium, or harmony in the domains of home/work-school/ health where adult wellbeing is concerned (Dodge et al., 2012). However, Ben-Arieh and Frønes (2011), in their review of indicators of children's wellbeing, find the field "fragmented and lacking a unifying taxonomy [of indicators]" (p. 461). The definition of wellbeing to which I am drawn includes the entitlement, according to the UN Convention of the Rights of Children (1989), to "the freedom of choice". This reflects how Ben-Arieh and Frønes define wellbeing as a dynamic process, with, at its heart: "an understanding of the developmental relationship between today and tomorrow" (ibid 464), where teachers attend to the wellbeing of the present to exercise a positive influence on children's progress from childhood to adulthood. It is a journey that will include challenges and disappointments, what Cummins (2010) calls "life events", all of which require the competence and confidence to make agentive choices and decisions, as part of growing up and, indeed, of life itself.

The journey concept resonates with White's (2005) definition of wellbeing as process. The lack of absolute clarity of definition aligns with the concept of wellbeing as a dynamic and conceptual "mashup" and conflation of terms, emotions, objective indicators, and subjectivities, defying any unambiguous or concrete definition. However, mental health assuredly incorporates wellbeing, as the World Health Organisation (2017) asserts, and the subjective essence of wellbeing gives ownership to the individual. With regard to definition, what is important are the dialogic spaces that emerge for teachers and schools as a consequence of reflecting on definitions and the objective indicators and the subjectivities of wellbeing. Such dialogues will support strategies on how wellbeing can be centred in the primary school culture to incorporate the pupils' voice. I look next at the UK national guidelines for PSHE and the spaces that these offer for children to be supported and listened to.

\section{The Physical, Social, Health, and Economic (PSHE) CURRICULUM}

Research carried out by Gutman and Feinstein (2008) found that the school environment played an important role in children's social, emotional, and behavioural development and their wellbeing. For this to have maximum impact, wellbeing needs to be an identifiable part of the school culture and curriculum and not just an "add-on". It is essential that wellbeing as a concept and practice imbues the whole of the primary curriculum, in terms of content, values, and practice. Shatkin and Belfer (2008) reviewed global policy on children's mental health and wellbeing and found policies universally lacking and underdeveloped. They concluded that national and school policies needed to be explicit and targeted at the specific needs of young children and youth and the promotion of mental health and wellbeing. 
Axford (2009) emphasises the benefits of a multidisciplinary approach.

English schools have a strong tradition of pastoral care that is evidenced in the role of class teachers as the first port of call in giving individual care and support. There is a national PSHE programme that is age-related and divided into Key Stage 1 - Infants ages 4/5-7 and Key Stage 2 - Juniors 7/8-10/11. The Department for Education expects that schools will "equip pupils with a sound understanding of risk and with the knowledge and skills necessary to make safe and informed decisions" (DfE, 2020, n.p.) although the delivery is left to teachers to decide. Only in the Early Years is PSHE not a discrete subject and here it is suggested that this is "a good time to start exploring PSHE foundations" (ibid). Otherwise, PSHE is expected to be visible in the curriculum and to mesh with guidance generally with national curriculum guidelines on "Healthy Lifestyles". Teachers assess the pupils on their development in these areas and inspections evaluate provision and perceived impact.

There is a Programme of Study (PSHE Association, 2020, London: PSHE Association) that sets out a number (n) of defined "learning opportunities" in three core themes:

1. Health and Wellbeing $(n=36)$

2. Relationships $(\mathrm{n}=25)$

3. Living in the wider world $(\mathrm{n}=17)$

Theme 1, which I set out to explore, is sub-divided as follows and includes a number (n) of defined "learning opportunities":
A Health Physical wellbeing - this includes indicators $(n=10)$ regarding diet, sleep, hygiene, exercise, and play, e.g. H 5 ( $\mathrm{H}$ mirrors the first letter of the subtheme heading Health and Wellbeing) - "simple hygiene routines that can stop germs from spreading".

B Mental health - this includes feelings, moods and emotions, sharing, supporting others, and seeking support ( $n=10)$, e.g. H16 - "about ways of sharing feelings; a range of words to describe feelings".

C Ourselves, growing, and changing - this includes our uniqueness, likes and dislikes, the body, growing up, identity, one's strengths and weaknesses $(\mathrm{n}=7)$.

D Keeping safe - hazardous substances, accidents and first aid, personal information and online safety $(\mathrm{n}=8)$.

E Drugs, alcohol, and tobacco - the impact, risks, and the law $(\mathrm{n}=1)$.

The learning requirements and opportunities that are suggested are extensive and need careful planning in and across the curriculum. The PSHE provision of both schools in this study, drawing on the national guidelines, was well-defined and framed within its own context, and the class teachers were highly attuned to their pastoral role. How I discovered this I explain in the next section.

\section{MeTHOD: A SMALL-SCALE EXPLORATORY STUDY}

The research question "How do these schools understand and enact wellbeing for the children, and their teachers?" is an 
acceptably "exploratory and fluid" question, according to Mason (2002, p. 20), and one that I considered would be best investigated in a small-scale exploratory study. Small-scale exploratory studies have their place within the paradigm of qualitative research. Such small studies of cases offer detail, nuance, and contextuality and make a "contribution to knowledge, insight, and professional practice" according to Punch and Oancea (2014, p. 47). I spent three days in each of two schools in a town in south-east England. The schools were very different from each other, one serving a very affluent middleclass area, the other a much more diverse and under-privileged intake. I chose them because I was aware of their reputation for their profound culture of caring for children. In addition, they were both schools in which I had previously felt comfortable and welcomed.

I spent three days in each school during January and February 2020; time was short because of the impending pandemic. I used the following methods of data collection: semi-structured interviews, one with the class teacher and one with the head teacher. Interviews are a useful and flexible technique for seeking views from people on topics of mutual interest, as Kvale (2007) writes. I also made maximum use of observation, including a lesson in the top infants' class and general observations around the school which produced spontaneous and valuable information about the school and class practices. I wandered round the school, sat in the school reception as a bystander, and en- gaged in general chat with staff members and pupils as they passed by. I observed keenly all that I could see, aligning with Mason's methodological "discipline of noticing" (2001), noting down details and reflections on what I saw and heard. I carried with me a notebook for contemporaneous note-taking and a few key prompts for the semi-structured interviews with the head teachers and teachers, which included asking:

- why children's wellbeing concerns had assumed priority in modern times

- how wellbeing in terms of physical, emotional, and social development was promoted through the PSHE programme and school culture

- about teacher wellbeing

I decided against recording, given the shortness of time and the fact that note-taking is less intrusive than recording (Baxter et al., 2010).The utmost care was taken to be sensitive, friendly, and ethically sound in this endeavour where young children were in the environment. I shared my observations with the teachers with whom I talked and engaged in meaningful dialogue so as to understand their perceptions of wellbeing, strategies, and feelings in their contexts and from their perspectives.

My focus on the daily life of the school and how wellbeing "felt" and looked enabled me to seek evidence according to the "learning opportunities" previously described. I analysed my data against these "learning opportunities" (H "learning opportunities for PSHE programme of study Core theme 1 - Health and mental well- 
being") and have tabled for each school which opportunities were evidenced. I structure the overall description of each case, schools $\mathrm{A}$ and $\mathrm{B}$, in the following way:

- Context and policy

- Programme of study Core theme 1 - Health and Wellbeing - learning opportunities

- Teacher wellbeing

- Table of evidence for the "learning opportunities"

The headings, followed by the tables for precision to provide rigour and confidence in the findings, enable my observations to be presented in a holistic way to give a flavour of each school's wellbeing culture. The choice of a small-scale exploratory study based on observation and interviews proved fit for purpose in obtaining insightful data and in enabling valid interpretation.

\section{School A context and policy}

School A is a mixed state school with 400 pupils. It is located just out of town in a pleasant residential area of the town. It is very close to a secondary school with which it has close links. It is a high-achieving school in terms of its national test results at age ten in the last year of primary schooling and a high number of children pass the area test for admission to one of the selective schools. The buildings are light and bright, its rooms and corridors richly decorated with children's art work, and it is surrounded by playing fields.

There is a written whole-school policy on wellbeing. It is a policy that permeates every aspect of the school day. Each classroom has posters on the dimensions of the wellbeing policy - The six ways to Wellbeing: body - be active, mind - keep learning, spirit - give, people - connect, places - take notice, planet - care. These dimensions are incorporated into the schemes of work and into the weave of the whole school day. The children engage with these in school across the curriculum, for example, many topics key into "Planet care" in considering how to be "green" and planet-friendly in Science and in good daily habits.

These "six ways" are shared with parents/carers at home and families are invited to support the "ways" generally and in specific activities such as litter collection from the nearby beach and recycling items into boxes provided at the school entrance. I saw extensive correspondence with parents about learning aims, and how they could support their children in their learning generally. The parents are fully on board with the aims and values of the school. The pupils are asked to provide evidence of their own personalised efforts from home, with descriptions, photos, etc. recorded in a home-learning book. There is a large number of activities for pupils to engage in outside formal lessons, and children's contributions are praised, efforts rewarded, and a constant stream of achievements, both large (winning an inter-school football match) and small (making cookies for a school charity bake-sale), recorded on the school's website. PSHE has space in the curriculum and is conducted often as a circle time activity (children sit in a circle for informal discussion and activities). 


\section{Programme of Study Core theme} 1 - Health and Wellbeing - "learning opportunities" school A

Children in need are offered breakfast before school starts. Aligning personal wellness with mental health, the whole school runs round the school buildings every morning in an act of communal physical wellbeing, although not in competition. There is a day learning plan that is shared on a whiteboard in each classroom with the children. The expectations are clear. There are recognisable subjects of English, Science, and Maths, for example, and others, all designed thematically on a cross-curricular and skills basis. I saw, for example, work around Greek Legends with wonderful Art work, story-crafting - highlighting "children as writers" - and group discussions about the concept of heroic acts and tragedies. Here, the children worked collaboratively, helping each other, giving peer assessment, feedback, and encouragement. The children were well practised in identifying their strengths and weaknesses and knew how to get help to improve their work.

As far as the emotional development and wellbeing of the children are concerned, the children engage with these in a very overt manner. On arrival in class every day, each child goes to a big jar full of coloured balls to find their ball with their name on it, which they then put into

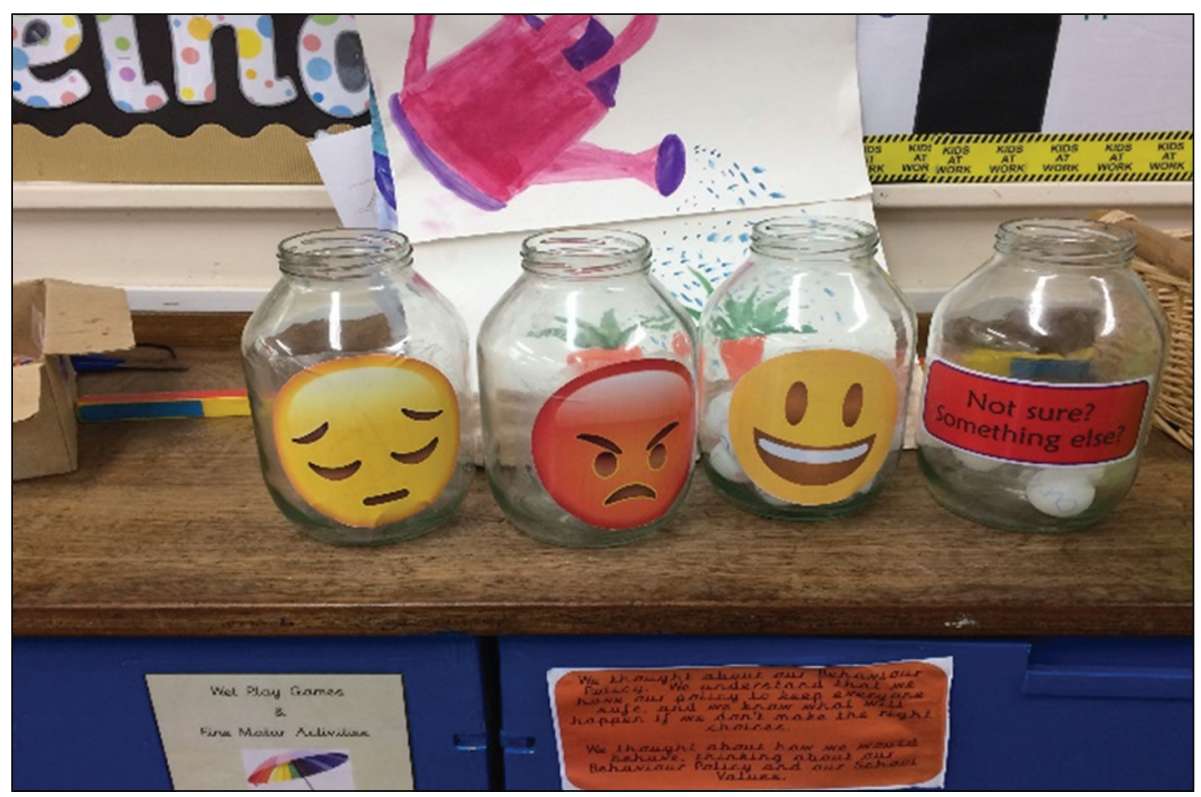

Figure 1 Jars of emoticon balls 
the relevant "feeling jar" labelled with an emoticon to reflect the way they are feeling. This process is repeated after morning playtime, after lunch, and, indeed, at any time that a child wishes to use the jars (Figure 1).

The teacher I spoke to told me that she monitors discreetly what is going on and will have a word with any child using the "angry" or "sad" jars, encouraging them to move to the happy or "something else" jars when they can: "I am proactive, watching their activity. I check all the balls and speak to those who are not happy or feeling angry, I might sometimes just sit with them." She emphasised how important it was to speak openly about emotions and wellbeing for, she continued: "If you are not feeling good then you can't learn." The teacher also encouraged the children to talk to each other and to provide peer support "in the way that only children can do for each other, in their own language". Whilst the children were encouraged to confront their own feelings openly, the school believes that it is important that this individuality is framed within the learning community at class level and mirrored at the level of the whole school, for example, in whole school assemblies. At the end of each school day, teachers ask the class about the day they have had as a class. The teacher I spoke to has various weather signs - clouds, sun, storm, rain - above the classroom clock and the children as a group decide what weather sign to put up at the end of the day. The last words spoken by the teacher at the end of class every day pertain to wellbeing. The children leave school with some positive notion in their heads. Some children will go to homes where this is reinforced, others, who are less fortunate, will, it is hoped, be able to "bank" some positive emotion and develop resilience in the face of disadvantage. No child goes home with their ball in the sad or angry jar.

Below I have tabulated the evidence seen/presented to me in school A against the $\mathrm{H}$ (Health) "learning opportunities" in the core theme Health and Wellbeing in the Programme of Study (Table 1).

\section{And what about teacher wellbeing?}

It can be seen that the children have many issues that challenge their wellbeing. They also learn and demonstrate remarkable coping strategies. The teachers also face wellbeing challenges and are proactive in confronting these. The teacher in school A felt that their wellbeing was taken very seriously. Teachers do a lot of shared planning with each other, lightening the load by collaborating. The classrooms are well equipped, with quality technology and clean modern furniture. She commented that the head was very approachable and that dropping in for coffee and chat was almost always available. Tea and sandwiches were made available at staff meetings and parents' after-school meetings. Every teacher gets a day off for Christmas shopping (the head takes the classes) and teachers are all allowed one late start at mid-morning a week (teaching assistants taking over) to enable them to make appointments, go shopping, etc. Above all, teachers had some time - the 
Table 1 Core theme learning opportunities and evidence

\begin{tabular}{|c|c|}
\hline $\begin{array}{l}\text { Core theme Health and Wellbeing } \\
\text { learning opportunity (abbreviated) }\end{array}$ & Evidence \\
\hline $\begin{array}{l}\text { H1 Keeping healthy. H2 Food that } \\
\text { supports good health }\end{array}$ & $\begin{array}{l}\text { Healthy breakfast and lunch provided in school; } \\
\text { free fruit available for children at playtime }\end{array}$ \\
\hline H3 Physical activity to keep healthy & $\begin{array}{l}\text { Physical activity, running round the playing field, } \\
\text { weekly Physical Education classes; games and } \\
\text { interschool sports }\end{array}$ \\
\hline $\begin{array}{l}\text { H5 Simple hygiene rules that can stop } \\
\text { germs from spreading }\end{array}$ & $\begin{array}{l}\text { Hand-washing frequently, using the hand sanitiser } \\
\text { independently }\end{array}$ \\
\hline $\begin{array}{l}\text { H11 Different feelings that humans can } \\
\text { experience }\end{array}$ & $\begin{array}{l}\text { Asking children how they feel at the beginning and } \\
\text { end of the day and teacher monitoring changes } \\
\text { throughout the day }\end{array}$ \\
\hline $\begin{array}{l}\text { H12 Recognising and naming different } \\
\text { feelings }\end{array}$ & The emoticon balls in the jars - children's choice \\
\hline $\begin{array}{l}\text { H14 Recognising what others might be } \\
\text { feeling }\end{array}$ & $\begin{array}{l}\text { Open discussions about emotions and feelings } \\
\text { in PSHE circle time activities; attentiveness } \\
\text { to friends/peers }\end{array}$ \\
\hline $\begin{array}{l}\text { H16 Ways of sharing feelings and } \\
\text { a range of words to describe feelings }\end{array}$ & $\begin{array}{l}\text { Peer support for children who are upset; peer } \\
\text { celebration of children's achievements }\end{array}$ \\
\hline $\begin{array}{l}\text { H18 Managing "big" feelings, calming } \\
\text { down and changing feelings when not } \\
\text { feeling good. }\end{array}$ & $\begin{array}{l}\text { Quiet word with the teacher; teacher or teaching } \\
\text { assistant takes a child for a walk round the } \\
\text { playground. }\end{array}$ \\
\hline $\begin{array}{l}\text { H19 Recognising when you need help } \\
\text { with feelings }\end{array}$ & $\begin{array}{l}\text { Going to change the emoticon and talking to the } \\
\text { teacher about why }\end{array}$ \\
\hline $\begin{array}{l}\text { H20 About change and loss and coping } \\
\text { with feelings associated with these }\end{array}$ & $\begin{array}{l}\text { Talking in class about e.g. loss of life or disaster as seen } \\
\text { on the news or experienced in their own families, done } \\
\text { in circle time or as cases arise. Climate change discussion }\end{array}$ \\
\hline $\begin{array}{l}\text { H23 Identify what are you good at, } \\
\text { what you like and dislike }\end{array}$ & $\begin{array}{l}\text { The children often worked in pairs and groups and } \\
\text { were effective users of both peer and self-assessment } \\
\text { of their work and were able to justify their opinions }\end{array}$ \\
\hline H24 Managing when things are difficult & $\begin{array}{l}\text { Discussing coping strategies and work-arounds with } \\
\text { individuals and in circle time; peer support and } \\
\text { coaching }\end{array}$ \\
\hline $\begin{array}{l}\text { H29 Recognising risks in everyday } \\
\text { situations and action to take to avoid } \\
\text { them }\end{array}$ & $\begin{array}{l}\text { The "no talking to strangers" rule, having contact } \\
\text { numbers to call the police and ambulance service, } \\
\text { avoiding strange substances; pandemic rules }\end{array}$ \\
\hline $\begin{array}{l}\text { H34 Basic online safety and keeping } \\
\text { personal data private }\end{array}$ & $\begin{array}{l}\text { Given the prevalence of online accessibility, circle } \\
\text { time talks about online dangers and careful use }\end{array}$ \\
\hline
\end{tabular}


most precious commodity - to themselves. A strategy can be seen here for alleviating stress, in making classroom and school life as agreeable as possible and collegial.

\section{School B context and policy}

School B is a small mixed state denominational school with 150 pupils. It is a school that aligns itself with the teachings of the Church of England and some of the school governors are appointed by the local church. It is situated in the centre of town, separated from the high street by the church grounds. It is located in a very mixed area, touching on parts of town that are quite affluent and also on parts of town with immense social deprivation. Given its very mixed intake, its national test results are very good and ever-improving. Housed in an old historical building with some modern extensions, the school is richly decorated with children's art work, plants, Bible quotations, and wellbeing posters. The building is hemmed in by other buildings but there is a small playground with outdoor games, a quiet sitting corner, and mini-flower and vegetable gardens.

There is a written school policy based on supporting the wellbeing of each child within the whole school wellbeing culture. The policy is framed by a Christian ethos and the values of the church that is adjacent to the school and hosts not just religious events but also cultural activities and parent groups. The entrance area is decorated with motivational messages, linked to the school's six core values of generosity, compassion, honesty, forgive- ness, respect, and perseverance, which are also visible in each classroom. The values are embedded and enacted in lessons; for example, the children are expected to listen carefully to and help each other and be polite and welcoming to visitors.

The parents and carers are considered partners in the education of their children and essential to the school wellbeing mission. Parents are welcomed to special events and teachers always "meet and greet" parents before the school day and at its end. The teachers provide weekly newsletters and an ongoing online pictorial blog about the children's achievements. Parents are kept well informed about the topics and themes to be covered and suggestions made about how to help. Parents attend some of the events in the Church. The parent support group is very active and very generous in the provision of items for the school, and always available as extra pairs of hands. A huge sense of pride is generated and achievements reflect not just individual efforts but those of a class, a group of children, indeed the whole school.

\section{Programme of study Core theme 1 - Health and Wellbeing - learn- ing opportunities school B}

There is a well-attended breakfast club, with many children from poor families. Once all the children are in their classroom, each day begins quietly with a prayer and reflection, and then the teacher explains the daily work plan. Every child's learning is monitored throughout the day, each teacher having a full-time 
teaching assistant. The children are well supported, and, as a result, develop good measures of confidence and resilience. Generally, their behaviour is exemplary.

There are the core subjects of English, Maths, and Science and many other National Curriculum subjects such as History, all presented on a thematic basis to teach and reinforce basic skills. I observed Science work taking place on light, darkness, and shade using a "light box", the children undertaking experiments in a pitch-black room, with torches and shadow games. There was a great deal of moving around, working in pairs and groups, collaborating, and giving feedback.

The children's general wellbeing is high on the agenda for each day, reflecting the considerable emotional needs of many of the pupils. The teacher I observed asked the children not only about their learning but how they were feeling

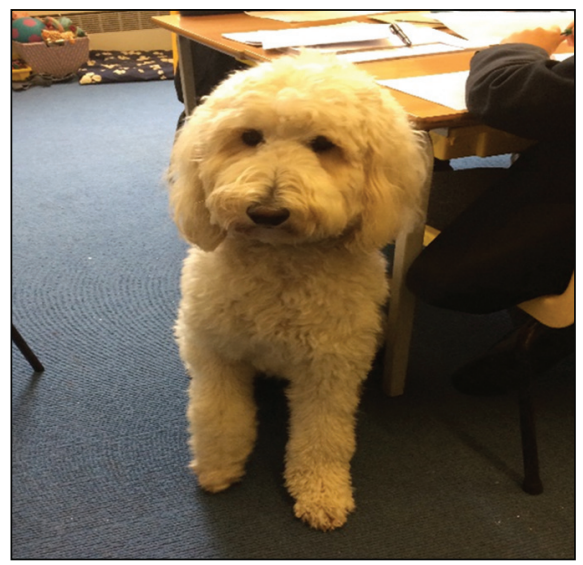

Figure 2 School therapy dog about their learning. School is the only safe haven for some children and, to further support the children's wellbeing needs, this school has the service of an educational psychologist in the school and also a fully qualified pet therapy dog that belongs to a teacher (see the dog sitting by a child, Figure 2).

The dog spends time in classrooms and is available for children to be comforted or for children who, shy about reading to an adult, prefer to read to the dog (with the teacher strategically placed to listen). The dog is very responsive and empathetic. Sometimes the dog is explicitly part of a lesson, e.g. about the animal kingdom or to illustrate values such as caring and kindness. The dog goes into the playground and is taken care of by children on a rota. I was told that the dog was probably the most popular living being in the school and added immense value to children's wellbeing. The teacher I spoke to commented that "Sometimes a child cannot express their feelings to their teacher but they can to the dog. So, if a child is upset, we let them sit with the dog or walk around the playground with her." As with school A, the teachers try to ensure that no child goes home feeling upset in any way. This is part of helping the child to cope with personal challenges.

Below I have, as for school A, tabulated the evidence against the $\mathrm{H}$ (Health) "learning opportunities" in the core theme Health and Wellbeing in the Programme of Study (Table 2). 
Table 2 Core theme learning opportunities and evidence

\begin{tabular}{|c|c|}
\hline $\begin{array}{l}\text { Core theme Health and Wellbeing } \\
\text { learning opportunity ( abbreviated) }\end{array}$ & Evidence \\
\hline $\begin{array}{l}\text { H1 Keeping healthy. H2 Food that } \\
\text { supports good health }\end{array}$ & $\begin{array}{l}\text { Healthy food at the breakfast club and school lunches (both } \\
\text { free for Infants). Free fruit at playtime and to take away }\end{array}$ \\
\hline H3 Physical activity to keep healthy & $\begin{array}{l}\text { Physical Education on the timetable, trampolining, } \\
\text { playground games, and trips to the local sports field and } \\
\text { swimming pool }\end{array}$ \\
\hline $\begin{array}{l}\text { H5 Simple hygiene rules that can } \\
\text { stop germs from spreading }\end{array}$ & $\begin{array}{l}\text { Frequent hand-washing and hand sanitisation by the } \\
\text { children. Older pupils helping younger ones }\end{array}$ \\
\hline $\begin{array}{l}\text { H10 About the people who help us } \\
\text { to stay physically healthy }\end{array}$ & $\begin{array}{l}\text { School visit by a local dentist for a whole school } \\
\text { assembly presentation }\end{array}$ \\
\hline $\begin{array}{l}\text { H11 Different feelings that humans } \\
\text { can experience }\end{array}$ & Morning reflection by teachers setting a positive context \\
\hline $\begin{array}{l}\text { H14 Recognising what others might } \\
\text { be feeling }\end{array}$ & $\begin{array}{l}\text { Compassion is a core element of the school values. } \\
\text { Considerable contact with the elderly nearby to combat } \\
\text { their loneliness }\end{array}$ \\
\hline $\begin{array}{l}\text { H16 Ways of sharing feelings and } \\
\text { a range of words to describe feelings }\end{array}$ & $\begin{array}{l}\text { Children-led worship on various associated themes, } \\
\text { examples of which are sadness/anxiety, "being a new } \\
\text { pupil", "what if I am scared", and "let's celebrate..." }\end{array}$ \\
\hline $\begin{array}{l}\text { H18 Managing "big" feelings, } \\
\text { calming down and changing feelings } \\
\text { when not feeling good }\end{array}$ & $\begin{array}{l}\text { Sharing with the teacher or teaching assistant and } \\
\text { walking or sitting with the therapy dog }\end{array}$ \\
\hline $\begin{array}{l}\text { H19 Recognising when you need } \\
\text { help with feelings }\end{array}$ & $\begin{array}{l}\text { Strong message (posters around school) that "It is OK to } \\
\text { share". Therapy dog available to talk to }\end{array}$ \\
\hline $\begin{array}{l}\text { H20 About change and loss and } \\
\text { coping with feelings associated with } \\
\text { these }\end{array}$ & $\begin{array}{l}\text { Occasional assemblies in church; the regularity of } \\
\text { funerals taking place adjacent to the school and } \\
\text { discussions about these; giving aid for major disasters }\end{array}$ \\
\hline $\begin{array}{l}\text { H23 Identify what are you good at, } \\
\text { what you like and dislike }\end{array}$ & $\begin{array}{l}\text { Lots of peer and self-assessment in lessons and the use of } \\
\text { the "two stars and a wish" format (two good points, one } \\
\text { for development) }\end{array}$ \\
\hline $\begin{array}{l}\text { H24 Managing when things are } \\
\text { difficult }\end{array}$ & $\begin{array}{l}\text { Quiet talks with the teacher, counsellor, or head teacher } \\
\text { and planning coping strategies }\end{array}$ \\
\hline $\begin{array}{l}\text { H29 Recognising risks in everyday } \\
\text { situations and action to take to avoid } \\
\text { them }\end{array}$ & $\begin{array}{l}\text { Child-friendly non-frightening messages about not touching } \\
\text { harmful substances (such as are sometimes left in the } \\
\text { adjoining churchyard). The "no talking to strangers" rule. } \\
\text { Emergency contact numbers. Pandemic procedures }\end{array}$ \\
\hline $\begin{array}{l}\text { H34 Basic online safety and keeping } \\
\text { personal data private }\end{array}$ & $\begin{array}{l}\text { Circle time discussion and a talk from the head teacher } \\
\text { about the dangers of online activity and advice to use } \\
\text { only with parental supervision }\end{array}$ \\
\hline
\end{tabular}




\section{And what about teacher wellbeing?}

It can be seen that these children in school B also face a great many challenges. They respond reflectively and with active engagement. The teachers also face challenges in their quest to support the children's wellbeing. The teachers make every effort to meet the children's every need. To value the teachers' efforts, the school has enacted a series of very practical strategies that included a half day free each week for each teacher, when their associated teaching assistant took their classes, an early start and early finish for the teachers on Fridays, meetings with tea and cake, and counselling services for teachers if needed. These strategies were designed to give teachers some choices about what they would like to do and some time to go about their personal lives and to be able to attend to their own needs as ordinary people. To enable this to happen, the teachers helped each other and stood in for each other, acting as positive role models of collaboration and generosity for the children. The head teacher said she gained her sense of wellbeing from "seeing the children being and doing well". It is the reciprocity of child and teacher wellbeing that creates the important school culture of wellbeing.

\section{Discussion}

\section{Health and wellbeing - physical and mental wellbeing}

Both schools had government funding for a breakfast club, and free school lunches for all infants as per UK Govern- ment policy. The children were thus well fed during school time but as the head teacher of school B said: "We worry about the children's eating in the school holidays." In both cases the local retail community, indeed for the benefit of all the schools in their locale, donated and delivered surplus food for families in need to collect from the school. The wellbeing of children goes beyond the school where physical wellbeing is concerned and becomes a community project but, crucially, the school is the point of activation of the services. Distributing food is quite a burden on the schools but is undertaken in collaboration and partnership with businesses in the locality. Both schools took physical wellbeing very seriously, with Physical Education in school and special sports days. School A had a surplus clothing box that included donated school uniforms. School $\mathrm{B}$ also had school uniform items available and a washing machine to wash children's clothes as necessary on a daily basis. Interestingly, both schools, as with most primary schools in the UK, have a uniform, school A having rather simple generic items, whereas School B has a uniform that is very recognisable, rather old-fashioned, and reminiscent of private schools. The children and parents at both schools were vehement in their desire to retain their particular uniform on the grounds of specialness and identity. Such voices represent meaningful choice and agency, as Redmond (2008) argues cogently.

Mental health is clearly aligned with physical good health and, in both cases, the schools were highly focused on good 
mental health and emotional development for each individual, and within the school community. The schools provided a safe space for playing, learning, and just "being". As I have written elsewhere, school is often the only haven of safety and security for some children and the only place where learning can take place: "Just "being there" is an important factor, providing the only point of security for those with chaotic lives" (Jones, 2017, p. 371).

Mental health was also visible in the social skills I observed, children interacting with each other sensibly and with adults respectfully. I also heard about children in school A welcoming "new arrival" children (e.g. immigrants) and the children in school B undertaking "random acts of kindness" with senior citizens, e.g. spending time talking to them, singing to them, and performing.

Both schools emphasised the importance of partnership links with parents. Indeed, the parent/family-child relationship and the amount of time invested by the family in that relationship is of relevance to wellbeing. Ferguson (2006, p. 2) writes that research has shown that social capital is "a social resource [that] can facilitate positive outcomes with respect to a broad range of social phenomena related to children's and youth's wellbeing". The pupils at School A, mainly from fairly affluent and stable backgrounds, tended to have considerable social capital according to the head teacher. School B, with a higher deprivation factor, planned the curriculum explicitly around cultural enrichment and socialisation opportunities to be inclusive of families where possible in order to enhance social capital.

The wellbeing focus that criss-crosses the whole curriculum and academic and pastoral programme (PSHE) identifies and plans for physical and mental health and wellbeing both explicitly and tangentially in the whole school culture and values. The children have a clear orientation in their work and expectations of their behaviours. The teachers are clear about the necessary conditions for learning, as the head of school B said: "The children cannot learn if they are not well in all ways. They need to have had something to eat and know what they are doing and how to do it." This was echoed by the head of school A, who said: "Wellbeing for me is when children can come to school and feel $O K$ about themselves and are ready and happy to learn." The children generally gave a good impression of feeling and being well, having a sense of personal daily purpose and being part of a class, a school, a community. The same was iterated about teacher wellbeing, which, as noted, was taken very seriously for the teachers' own mental health but also because the pupils experience their teachers' wellbeing vicariously in their relationships with their teachers. The wellbeing of the children and the wellbeing of the teachers are inextricably and emotionally interlinked. Heads have a duty of care to staff wellbeing in recognition of teachers as human beings and for their time invested in the wellbeing of children, which goes considerably beyond regular teaching hours and plans. 
The children were not shielded from world, national, and local disasters - the media would make this impossible - but rather the children were encouraged to think about issues constructively and develop a positive and "coping" mindset towards change, difference, disasters, and the cycle of life. The children in both schools were greatly touched by the plight of wildlife in the Australian bush fires of 2019, for example, and made generous donations through activities of their choice. The children in school B frequently hear the bells tolling for funerals in the nearby church. As part of growing up, children experience challenges, difficulties, and disappointments in their own lives. Of relevance here is the research of Fattore et al. (2007), based on self-reporting by children and young people that showed that in their view, an important wellbeing indicator was to have "feelings of happiness but also the ability to integrate sadness into one's life and be able to deal with it" (p. 11). A prime aim of the wellbeing agenda is to help children to build resilience and confidence so that they can cope constructively with challenges and life choices. Noticeably, the children in both schools faced the 2020 virus pandemic with fortitude, although naturally they were a little anxious, and made their contributions to support community wellbeing in helping others. Morrow and Mayall (2009) urge that wellbeing be seen positively through the prism of what makes children feel well and how they feel empowered to act, since this is how children themselves report their wellbeing.

\section{Conclusion}

The purpose of this article was to explore how wellbeing is understood and enacted by young children and their teachers in two primary school settings. My research question was: How do these schools understand and enact wellbeing for the children, and their teachers? I have provided a picture of how the two schools do that, with evident attention to individual children's needs but also with whole-school strategies that create a wellbeing culture. The importance of the teacher role cannot be overestimated. The teacher is the one with daily contact and in a prime position to know and understand each child over an extended period. Teacher professional development with regard to wellbeing is important so that teachers can be well informed in order to have the best possible insights and develop a range of strategies and resources (Kern et al., 2014). This is especially so for children who are vulnerable and need attentive support for their fragile sense of wellbeing. Teachers are often judged by the examination grades that their students achieve, which is seen as an objective measure. The subjective wellbeing of children and teachers also needs to be an important evaluative factor of school success. The head teacher has a pivotal role in ensuring a school culture that focuses on conditions for learning and wellbeing for the children and teachers.

At the beginning of this article, I commented on wellbeing as a complex construct of objective indicators and of 
subjectivities, i.e. the ways in which individuals perceive their personal wellbeing. According to Barblette and Maloney (2010, p. 13), emotional competence is socially and culturally constructed and, crucially, "meanings belong to the child, not the assessor [teacher]". In other words, we must recognise that the children have ownership and choices and are capable of some insight into their own sense of wellbeing. This ownership was well demonstrated in both schools, where the children made personal assertions about their feelings and had opportunities to express these. They also had the opportunity to choose the activities they would like to do at certain times in the day. An additional dimension of choice was behavioural and taking some responsibility for choosing to behave well and appropriately. Lash and Belfiore (2017, p. 2) for the Next Generation Leading Challenge (NGLC) initiative propose a series of strategies for schools to promote "habits of success", for example, "creative knowhow" and "wayfinding ability". Pupils had leadership and responsibility opportunities in both schools, as the data shows, which encouraged coping strategies, creativity, positivity, and success. Indeed, the ways in which the children took on these roles for themselves and reached out to others was impressive. The children in this study exhibited confidence, resilience, and great sensitivity to the wellbeing of others, as well as taking a measure of responsibility for their own wellbeing, thus developing effective "wayfinding abilities" in their young lives. Schools need to be critically reflective about and responsive to the absolute entitlement to wellbeing of children in the school in a dialogue in which the children themselves have a voice and a crucial measure of control over their lives.

By way of final reflections, I find the comment from a teacher in school B apposite; she said that "children cannot learn if other things are not in place. We have to look to see that these things are in place". The school's function is not only to promote learning but also to ensure that the conditions for learning are in place, focusing on children's wellbeing from all perspectives. It also involves connecting with parents/carers and the whole community to provide the potential for wellbeing for all. White (2005, p. 15) emphasises the importance of this relational dimension of wellbeing: “... at its best, a collective project to enhance wellbeing".

These insights from this small-scale study add to the developing picture of evidence about the development of primary schoolchildren's wellbeing. Having an effective, shared PSHE-type programme in the primary school provides a structure in which to develop and monitor wellbeing. The primary school culture is arguably a good place for children not only to engage in purposeful learning but also to have opportunities to articulate, grow, and enact their own wellbeing and the wellbeing of others. 


\section{REFERENCES}

Axford, N. (2009). Child well-being through different lenses: Why concept matters. Child and Family Social Work, 14, 372-383.

Barblett, L., \& Maloney, C. (2010). Complexities of assessing social and emotional competence and wellbeing in young children. Australasian Journal of Early Childhood, 35(2), 13-18.

Ben-Arieh, A., \& Frønes, I. (2011). Taxonomy for child well-being indicators: A framework for analysis of the wellbeing of children. Childhood, 18(4), 460-476.

Blaxter, L., Hughes, C., \& Tight, M. (2010). How to research. Maidenhead: McGraw Hill.

Bradshaw, J., \& Richardson, D. (2009). An index of child well-being in Europe. Child Indicators Research, 2(3), 319-351.

Bradshaw, J., Keung, A., Rees, G., \& Goswami, H. (2011). Children's subjective wellbeing: International comparative perspectives. Children and Youth Services Review, 33(4), 548-556.

Cummins, R. (2010). Subjective wellbeing, homeostatically protected mood and depression: A synthesis. Journal of Happiness Studies, 11, 1-17.

Department for Education. (2016). Mental Health and behaviour in schools. Departmental advice for school staff. London: DfE.

Dodge, R., Daly, A. P., Huyton, J., \& Sanders, L. D. (2012). The challenge of defining wellbeing. International Journal of Wellbeing, 2(3), 222-235.

Ereaut, G., \& Whiting, R. (2008). What do we mean by 'wellbeing'? And why might it matter? DCSF Research Report DCSF-RW073.

European Commission. (2011). Well-being. Aggregate report. September 2011. Eurobarometer qualitative studies. Brussels: European Commission.

European Commission. (2008). Child poverty and well-being in the EU: Current status and way forward. Brussels: European Commission.

Fattore, T., Mason, J., \& Watson, E. (2007). Children's conceptualisations of their wellbeing. Social Indicators Research, 80(1), 5-29.

Ferguson, K. M. (2006). Social capital and children's wellbeing: A critical synthesis of the international social capital literature. International Journal of Social Welfare, 15, 2-18.

Gutman, L. M., \& Feinstein, L. (2008). Determinants of aspirations. London: Centre for the Wider Benefits of Learning.

Jones, J. (2017). The role of the form tutor. In J. Dillon \& M. Maguire (Eds), Becoming a teacher. Maidenhead: McGraw Hill.

Kern, M. L., Waters, L., Adler, A., \& Mathew, M. (2014). Assessing employee wellbeing in schools using a multifaceted approach: Associations with physical health, life satisfaction and professional thriving. Psychology, 5, 500-513.

Kvale, S. (2007). Doing interviews. London: SAGE.

Lash, D., \& Belfiore, G. (2017). Five essentials in building social capital. Report 4 of the MyWays study success series. Columbus, Ohio: NGLC. 
Layard, R., \& Dunn, J. (2009). A good childhood: Searching for values in a competitive age. London: The Children's Society.

Li, Q. (2008). Cyberbullying in high schools: A study of students' behaviours and beliefs about this new phenomenon. Journal of Aggression, Maltreatment and Trauma, 19(4), 372-392.

Mason, J. (2001). Researching your own practice: The discipline of noticing. London: Routledge. Morrow, V., \& Mayall, B. (2009). What is wrong with children's well-being in the UK? Questions of meaning and measurement. Journal of Social Welfare and Family Law, 31(3), 217-229.

OECD (2019). What do we know about children and technology? Paris: OECD.

Office of National Statistics (2020). Estimates for income inequalities, UK: Financial year ending 2019. London: Gov UK.

Pedace, L. (2008). Child wellbeing in England, Scotland and Wales: Comparisons and variations. Research paper. London: Family and Parenting Institute.

PSHE Association (2020). Programmes of study for PSHE key stages 1-5. London: PSHE Association. Pollard, E. L., \& Lee, P. D. (2003). Child well-being: A systematic review of the literature. Social Indicators Research, 61(1), 59-78.

Punch, K. F., \& Onacea, A. (2014). Introduction to research methods in education. London: SAGE.

Redmond, G. (2008). Child poverty in perspective: An overview of child well-being in rich countries. Innocenti Report Card 7. Florence: UNICEF Innocenti Research Centre. Available from: http://www.unicefirc.org/publications/pdf/rc7_eng.pdf

Rees, G., Bradshaw, J., Goswami, H., \& Keung, A. (2009). Understanding Children's wellbeing: A national survey of young people's well-being. London: The Children's Society.

Shariff, S., \& Hoff, D. (2009). Cyber bullying: Clarifying legal boundaries for school supervision in cyberspace. International Journal of Cyber Criminology, 1(1), 76-118.

Shatkin, J., \& Belfer, M. (2008). Child and adolescent mental health policy worldwide. Board of International Affairs of the Royal College of Psychiatrists, 5(4), 81-84.

Sterling, S., \& Emery, H. (2016). A whole-school framework for emotional well-being and mental health. London: National Children's Bureau.

Stratham, J., \& Chase, E. (2010). Childhood wellbeing. A brief overview. Loughborough: Childhood Wellbeing Research Centre.

Steger, M. F. (2017). Meaning in life and wellbeing. In M. Slade, L. Oades \& A. Jarden (Eds.), Wellbeing, recovery and mental health. Cambridge: Cambridge University Press.

Tomlinson, M., Walker, R., \& Williams, G. (2008). The relationship between poverty and childhood well-being in Great Britain. Barnet Papers in Social Research, 3, 1-29.

United Nations (1989). Convention on the rights of the child. New York: UN Human Rights. White, S. (2005). But what is wellbeing? A framework for analysis in social and development policy and practice. University of Bath.

World Health Organisation (2017). Mental health incorporating wellbeing. New York: WHO. 
Jane Jones

Senior Lecturer in Modern Foreign Languages Education, Department of Education, Communication and Society, King's College London, United Kingdom;

e-mail:jane.jones@kcl.ac.uk

\section{JONES, J. Jak dvě anglické základní školy podporují wellbeing}

Článek pojednává o tom, jak dvě anglické základni školy podporuji wellbeing dètí mladšiho školního věku a jejich učitelu. Není již pravidlem, že by se o wellbeingu hovorilo pouze ve spojitosti s dospělými jedinci. Aktuálně narůstá zájem o dèti, které bývaji také vystavovány značnému stresu. V současné době žijeme ve svètě obav a tlaku, často vycházejicich ze zpráv a sociálnich médii, které maji dopad na život dètí. Školy ve Velké Británii mivaji dobrý pastorálni rád a jako základni princip prijaly požadavek zajistit wellbeing svých žákù a učitelu. Personálni, sociálni, zdravotni a ekonomická (PSHE) národni opatřeni pro školy v Anglii, která popisuji, konkretizuji požadavky na podporu fyzické a duševni pohody žáků. Na pozadi této politiky jsem se rozhodla sledovat život na dvou školách a na základè rozhovoru s rediteli a trídnimi učiteli téchto škol jsem se snažila odhalit, jaká opatřeni prijaly tyto školy pro podporu wellbeingu. Výzkumná otázka zní jednoduše: "Jak tyto školy chápou o wellbeing dèti a jejich učitelu a jak o nèj usiluji??"Školy byly vybrány, protože se kontextovè velmi lišily, ale v komunitě byly dobře známy excelentni pastorálni praci a zajištènim PSHE opatřeni. Zjištèni ukazuji, že ve zkoumaných školách je wellbeing snadno identifikovatelný jako "předmèt" v kurikulu primárního vzdèláváni a že je zakotven v kultuře školy a napričc kurikulem. Zjištění také zdiorazňuji diuležitost učitele, který je v každodennim kontaktu s žáky a má proto vynikajici pozici pro pozorováni, poznáváni a porozumèni každému ditèti. Učitelé zduraznili potřebu pomoci dètem budovat odolnost a sebediověru, které jim umožní využivat príležitosti a konstruktivnè se vypořádávat s výzvami při životnich rozhodnutích. Dospěla jsem k závèru, že celá kultura školy založená na wellbeingu je základem pro stanovení podminek, za kterých se dèti mohou učit a rozvijet svịj wellbeing ve škole i v širši komunitě.

Klíčová slova: wellbeing, duševni zdravi, primárni kurikulum, hlas žákü, kultura školy 